\title{
APLIKASI SISTEM PAKAR DIAGNOSA AWAL PENYAKIT MENULAR PADA BALITA BERBASIS ANDROID
}

\author{
${ }^{1}$ M. Afdal, ${ }^{2}$ Delicia Generis Humani \\ ${ }^{1,2}$ Program Studi Sistem Informasi, Fakultas Sains dan Teknologi UIN Suska Riau \\ J1. HR Soebrantas KM.18 Panam Pekanbaru - Riau \\ Email: ${ }^{1}$ m.afdal@uin-suska.ac.id, 2deliciagenerish@students.uin-suska.ac.id
}

\begin{abstract}
ABSTRAK
Masalah kesehatan yang paling banyak dan sering terjadi hampir di seluruh negara berkembang seperti Indonesia salah satunya adalah penyakit menular. Penyakit menular menjadi begitu penting kedudukannya dalam dunia kesehatan dan menjadi fokus bagi masyarakat global karena menimbulkan angka kematian yang relatif tinggi dalam kurun waktu yang relatif singkat. Penyakit sangat rentan dan cepat terhadap anak sehingga membuat orang tua sulit mengetahui atau mendiagnosa penyakit yang diderita oleh anak tersebut, dikarenakan balita belum dapat berbicara apa yang sedang ia rasakan. Keterbatasan tenaga paramedik khususnya dokter ahli anak dapat diatasi dengan mengadopsi kepakaran dokter ahli anak ke dalam suatu sistem berbasis komputer atau android yang mampu melakukan diagnosa layaknya seorang dokter ahli anak. Oleh sebab itu, penelitian ini membuat sistem pakar berbasis android. Menggunakan Metode inferensi Forward Chaining dengan 7 jenis penyakit pada balita dan 41 gejala, serta dilengkapi dengan solusi atau penanganan masing-masing penyakit menular pada anak balita. Pengujian sistem menggunakan 3 pengujian yaitu unit testing, blackbox test, dan user acceptance test. Hasil unit testing menunjukkan aplikasi berhasil menjalankan inferensi terhadap rule-rule yang dipilih dengan benar. Hasil blackbox yang dilakukan pada 10 smarthphone berjalan dengan tingkat keberhasilan $100 \%$. Hasil user acceptance test menunjukkan tingkat penerimaan aplikasi oleh pengguna sebesar $91 \%$.
\end{abstract}

Kata Kunci: Anak Balita, Android, Forward Chaining, Penyakit Menular, Sistem Pakar

\section{A. PENDAHULUAN}

Kesehatan merupakan kebutuhan yang sangat penting bagi kelangsungan hidup manusia. Menurut undang-undang No. 36 tahun 2009 tentang Kesehatan Pasal 1 ayat (1), kesehatan adalah keadaan sehat, baik secara fisik, mental, spiritual maupun sosial yang memungkinkan setiap orang untuk hidup produktif secara sosial dan ekonomis. Banyak faktor yang memengauhi kesehatan seseorang, baik faktor internal maupun faktor eksternal. Faktor internal yang dimaksud seperti faktor fisik atau psikis. Sementara itu faktor eksternal seperti budaya masyarakat, lingkungan fosok, ekonomi, pendidikan, dan sebagainya. Faktor lingkungan memiliki pengaruh paling tinggi terhadap status kesehatan. Para ahli kesehatan masyarakat sepakat bahwa lingkungan merupakan determinan utama derajat kesehatan penduduk[1].

Periode penting dalam tumbuh kembang adalah masa balita (bawah lima tahun). Anak balita pada usia 2 bulan sampai 5 tahun lebih rentan terhadap penyakit. Pada usia tersebut, balita lebih mudah terkena penyakit yang dari lingkunga yang tidak sehat. Berdasarkan riset yang dilakukan oleh pemerintah Indonesia penyakit atau masalah kesehatan yang menyerang balita masih berkisar pada yaitu gangguan perinatal, penyakit-penyakit infeksi, dan masalah kekurangan gizi.

Berdasarkan hasil Survei Penduduk Antar Sensus (SUSPAS) tahun 2015, angka kematian balita (AKABA) di Indonesia sebesar 26,29 per
1000 kelahiran hidup artinya setiap 1000 balita oada tahun 2015, sekitar 26 orang anak tidak bertahan hidup mencapai tepat lima tahun[2]. Selama beberapa tahun terakhir, AKABA di Indonesia mengalami penurunan tetapi masih termasuk tinggi dibandingkan negara tetangga seperti Malaysia dan Singapura.

Penyakit menular menjadi salah satu masalah kesehatan yang hampir semua negara berkembang termasuk Indonesia. Penyakit menular menjadi masalah kesehatan global karena menimbulkan angka kesakitan dan kematian yang relatif tinggi dalam kurun waktu yang relatif singkat. Penyakit menular adalah sebuah penyakit yang infeksi yang disebabkan oleh sebuah agen biologi, seperti virus, bakteria atau parasit. Penyakit ini dapat ditularkan dari satu orang ke orang lain, baik secara langsung maupun dengan perantara. Secara garis besar cara penularan penyakit menular dapat melalui langsung, yaitu dari orang ke orang, contohnya melalui permukaan kulit[3].

Berdasarkan data yang dipublikasi Badan Kesehatan Dunia (WHO) tahun 2015, Indonesia termasuk 10 negara dengan jumlah kasus campak terbesar di dunia. Kementerian Kesehatan Republik Indonesia mencatat kasus Campak dan Rubella yang ada di Indonesia sangat banyak dalam kurun waktu lima tahun terakhir. Adapun jumlah total kasus suspek Campak-Rubella yang dilaporkan antara tahun 2014 sampai dengan Juli 2018 tercatat 
sebanyak 57.056 kasus (8.964 kasus Campak dan 5.737 Rubella)[4].

Anak sangat rentan terhadap kuman penyakit sehingga sebagai orang tua perlu untuk secara cepat memperoleh informasi tentang tingkat keparahan penyakit anak walaupun tidak tersedia dokter ahli anak sehingga orang tua mempunyai pengetahuan yang cukup untuk melakukan tindakan awal[5].

Penyebaran kuman penyakit sangat rentan dan cepat terhadap anak yang berada dalam rentang usia 1-5 tahun. Sehingga membuat orang tua sulit mengetahui atau mendiagnosa penyakit yang diderita oleh anak tersebut, dikarenakan balita belum dapat berbicara apa yang sedang ia rasakan. Orang tua hanya dapat melihat gejala-gejala yang berbeda atau perilaku aneh yang diderita oleh sang balita, seperti kejang, demam tinggi, muntah, batuk, dan gejala lainnya

Pada umumnya, orang tua yang baru memiliki anak belum memiliki pengetahuan lebih mendalam tentang penyakit-penyakit yang diderita oleh anak balita. Pengetahuan orang tua mengenai penyakit pada anak balita lebih penting karena anak balita memiliki daya tahan tubuh yang belum sempurna dibandingkan dengan orang dewasa sehingga anak balita sangat rentan terkena penyakit. Oleh karena itu, dibutuhkannya seseorang yang ahli atau kompeten yang mengetahui tentang penyakit yang diderita oleh balita, yaitu seorang dokter ahli anak.

Penyakit campak (morbili), campak jerman (rubella), cacar air (varisela), sindrom pipi merah (eritema infeksiosa), impetigo, dan demam berdarah merupakan beberapa dari banyak jenis penyakit menular pada anak balita yang termasuk ke dalam konteks ruam kemerahan (Lampiran A). Ciri khas atau yang spesifik dari semua penyakit ini adalah disebabkan oleh infeksi virus dan menimbulkan munculnya ruam di permukaan kulit. Namun ruam pada setiap penyakit memiliki perbedaan, yaitu kapan waktu munculnya ruam, warna dan bentuk ruam, serta gejala yang dirasakan oleh anak balita. Penyakit campak, campak jerman, dan demam berdarah termasuk penyakit menular yang sangat besar di Indonesia, sehingga hal ini menunjukkan bahwa penyakit menular yang disebabkan oleh infeksi virus ini harus cepat didiagnosis dan ditangani agar tidak semakin parah. Namun demikian jumlah dokter spesialis di Indonesia belum mencukupi. Terutama spesialis anak, kandungan dan kebidanan, bedah, penyakit dalam, anestesi dan rehabilitasi medik[6].

Keterbatasan tenaga paramedik khususnya dokter ahli anak dapat diatasi dengan mengadopsi kepakaran dokter ahli anak ke dalam suatu sistem berbasis komputer yang mampu melakukan diagnosa layaknya seorang dokter ahli anak (Latumakulita, 2012). Sistem yang dimaksud adalah sistem pakar yang dapat mendiagnosa penyakit yang diderita oleh anak balita dengan menginputkan gejala-gejala yang diderita oleh balita, sehingga dari gejala tersebut sistem dapat mendiagnosa dan memberikan atau menampilkan informasi nama penyakit.

Sistem pakar adalah sebuah sistem yang menggunakan pengetahuan manusia, di mana pengetahuan tersebut dimasukkan ke sebuah komputer dan kemudian digunakan untuk menyesaikan masalah-masalah yang biasanya membutuhkan kepakaran atau keahlian pakar[7].

Berdasarkan penelitian yang dilakukan oleh Luther A. Latumakulita pada tahun 2012 menghasilkan sistem pakar untuk mendiagnosa penyakit anak dengan penanganan faktor ketidakpastian menggunakan certainty factor $(\mathrm{CF})$. Pengguna (user) akan memilih gejala-gejala penyakit yang dilihat atau dirasakan, maka sistem dapat mendiagnosa penyakit anak dengan menampilkan tiga penyakit dengan nilai $\mathrm{CF}$ terbesar yang diurutkan secara descending. Penelitian selanjutnya dilakukan oleh Pratiwi dkk pada tahun 2014 menghasilkan sistem pakar sebagai alat bantu untuk menentukan resiko terbesar penyakit demam yang diderita berdasarkan gejala-gejala fisik yang dirasakan.

Dalam hal ini, penulis tertarik melakukan penelitian untuk membuat sistem pakar berbasis android, menggunakan 7 jenis penyakit pada balita dengan 45 gejala, serta dilengkapi dengan solusi atau penanganan masing-masing penyakit menular pada anak balita.

Berdasarkan latar belakang di atas, maka penulis tertarik untuk meneliti dengan judul "Aplikasi Sistem Pakar Diagnosa Awal Penyakit Menular Pada Balita Berbasis Android”.

\section{B. LANDASAN TEORI}

\section{B.1. Sistem Pakar}

Sistem pakar adalah sebuah sistem yang menggunakan pengetahuan manusia, di mana pengetahan tersebut dimasukkan ke sebuah computer dan kemudian digunakan untuk menyesaikan masalah-masalah yang biasanya membutuhkan kepakaran atau keahlian pakar[7].

Karakteristik dan kemampuan yang dimiliki oleh sistem pakar berbeda dengan sistem konvensional.Perbedaan ini ditunjukkan oleh Tabel $1[8]$.

\begin{tabular}{|c|c|}
\hline Sistem Konvensional & \\
\hline $\begin{array}{lr}\text { Informasi } & \text { dan } \\
\text { pemrosesan umumnya } \\
\text { digabung dalam satu } \\
\text { program. }\end{array}$ & $\begin{array}{l}\text { Basis pengetahuan dipisahkan } \\
\text { secara jelas dengan mekanisme } \\
\text { pemrosesan (inferensi). }\end{array}$ \\
\hline $\begin{array}{lr}\text { Eksekusi } & \text { secara } \\
\text { algoritmik } & \text { (step by } \\
\text { step). } & \end{array}$ & $\begin{array}{l}\text { Eksekusi dilakukan secara } \\
\text { heuristik dan logis pada seluruh } \\
\text { basis pengetahuan. }\end{array}$ \\
\hline $\begin{array}{l}\text { Perlu informasi yang } \\
\text { lengkap agar bisa } \\
\text { beroperasi. }\end{array}$ & $\begin{array}{l}\text { Dapat beroperasi dengan } \\
\text { informasi yang tidak lengkap atau } \\
\text { ketidakpastian. }\end{array}$ \\
\hline Data kuantitatif. & Data kualitatif (pengalaman). \\
\hline $\begin{array}{lr}\text { Tidak } & \text { menjelaskan } \\
\text { mengapa } & \text { input } \\
\text { dibutuhkan } & \text { atau } \\
\end{array}$ & $\begin{array}{l}\text { Penjelasan (explanation) } \\
\text { merupakan bagian dari suatu } \\
\text { sistem pakar }\end{array}$ \\
\hline
\end{tabular}




\begin{tabular}{|c|c|}
\hline Sistem Konvensional & Sistem Pakar \\
\hline $\begin{array}{l}\text { bagaimana } \\
\text { diperoleh. }\end{array}$ & \\
\hline $\begin{array}{l}\text { Perubahan pada } \\
\text { program menyulitkan. }\end{array}$ & $\begin{array}{l}\text { Perubahan pada aturan-aturan } \\
\text { dapat dilakukan dengan mudah. }\end{array}$ \\
\hline $\begin{array}{lr}\text { Manipulasi } & \text { efektif } \\
\text { pada database yang } \\
\text { besar. }\end{array}$ & $\begin{array}{l}\text { Manipulasi efektif pada basis } \\
\text { pengetahuan yang besar. }\end{array}$ \\
\hline $\begin{array}{l}\text { Efisiensi adalah tujuan } \\
\text { utama. }\end{array}$ & itas adalah tujuan \\
\hline $\begin{array}{l}\text { Representasi } \\
\text { numerik. }\end{array}$ & $\begin{array}{l}\text { Representasi pengetahuan dalam } \\
\text { simbolik. }\end{array}$ \\
\hline $\begin{array}{lr}\text { Menangkap, } & \\
\text { menambah } & \text { dan } \\
\text { mendistribusikan } & \text { data } \\
\text { numerik } & \text { atau } \\
\text { informasi. } & \\
\end{array}$ & $\begin{array}{l}\text { Menangkap, menambah dan } \\
\text { mendistribusikan pertimbangan } \\
\text { (judgment) dan pengetahuan. }\end{array}$ \\
\hline
\end{tabular}

Ada dua bagian penting dari sistem pakar, yaitu lingkungan pengembangan (development environment) dan lingkungan konsultasi (consultation environment). Lingkungan pengembangan digunakan pembuat sistem pakar untuk membangun komponen-komponennya dan memperkenalkan pengetahuan ke dalam knowledge base (basis pengetahuan). Lingkungan konsultasi digunakan pengguna untuk berkonsultasi sehingga mendapatkan pengetahuan dan nasihat dari sistem pakar layaknya seorang pakar. Gambar 1 menunjukkan komponen-komponen yang penting dalam sebuah sistem pakar [8].

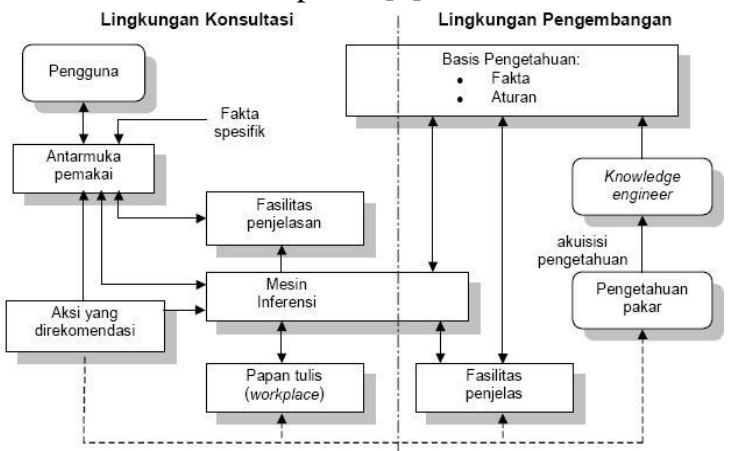

Gambar 1 Komponen Penting Dalam Sistem Pakar

\section{B.2. Forward Chaining}

Pelacakan ke depan (forward chaining) adalah pendekatan yang dimotori data (data-driven). Dalam pendekatan ini, pelacakan dimulai dari informasi masukan, dan selanjutnya mencoba menggambarkan kesimpulan. Pelacakan ke depan mencari fakta yang sesuai dengan bagian IF dari aturan IF-THEN[9].

Berikut menunjukan proses forward chaining pada gambar 2 di bawah.

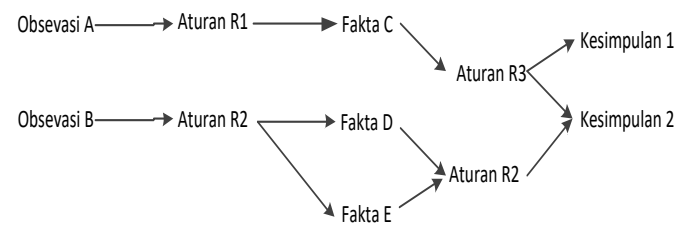

Gambar 2 Proses Forward Chaining

\section{B.3. Anak Balita}

Anak balita adalah anak yang telah menginjak usia di atas satu tahun atau lebih popular dengan pengertian usia anak di bawah lima tahun (Muaris. H, 2006). Menurut Sutomo. B. dan Anggraeni. DY, (2010), balita adalah istilah umum bagi anak usia 1-3 tahun (batita) dan anak prasekolah (3-5 tahun).

\section{B.4. Expert System Development Life Cycle (ESDLC)}

Expert System Development Life Cycle merupakan konsep dasar dalam perancangan dan pengembangan sistem pakar yang sering digunakan.

Gambar 3 berikut merupakan siklus pengembangan sistem pakar (Expert System Development Life Cycle - ESDLC).

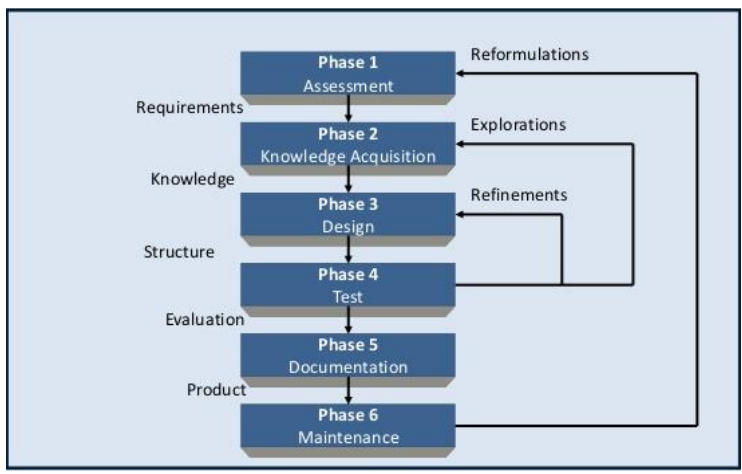

Gambar 3 Siklus Pengembangan ESDLC

\section{METODOLOGI PENELITIAN}

Berikut merupakan desain penelitian yang dilakukan terlihat pada gambar di bawah.

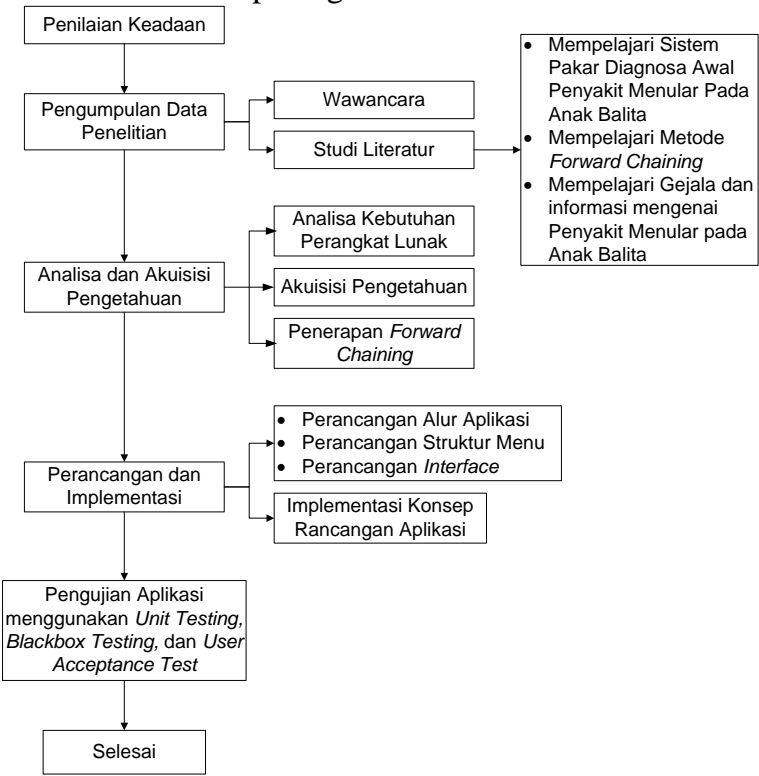

Gambar 4 Metodologi Penelitian

Gambar 4 menjelaskan mengenai tahap-tahap penelitian yang digunakan. Tahap awal adalah penilaian keadaan, yang dilakukan adalah mengidentifikasi masalah yang terjadi, mendefinisikan tujuan dan ruang lingkup yang terkait dalam membangun aplikasi sistem pakar. 
Jurnal Ilmiah Rekayasa dan Manajemen Sistem Informasi, Vol. 6, No. 1, Februari 2020, Hal. 55-63 e-ISSN 2502-8995 p-ISSN 2460-8181

Tahap berikutnya adalah pengumpulan data penelitian, yaitu dilakukan dengan cara wawancara (interview) dan studi literatur sehingga didapatkan data-data yang valid dalam melakukan penelitian ini. Tahap selanjutnya adalah analisa dan akuisisi pengetahuan, yaitu melakukan analisa kebutuhan data, menentukan sumber pengetahuan, mendapatkan pengetahuan yang berhubungan dengan masalah, serta mempelajari, menambah dan mengatur pengetahuan yang didapatkan dari wawancara kepada pakar (dokter spesialis anak). Tahap selanjutnya adalah perancangan dan implementasi, yaitu melakukan kegiatan yang dimulai dari mendefinisikan struktur sistem, metode yang akan dilakukan, membuat konsep rancangan sistem (mulai dari alur sistem, perancangan struktur menu, dan perancangan antar muka (interface) sistem). Tahap terakhir adalah melakukan pengujian sistem, dalam hal ini dilakukan 3 pengujian yaitu pengujian unit test, blackbox testing, dan pengujian user acceptance test.

\section{ANALISA DAN PERANCANGAN}

\section{D.1. Analisa Sistem Yang Sedang Berjalan}

Berikut adalah flowchart dari sistem yang sedang berjalan di masyarakat saat ini yang dapat dillihat pada Gambar 5.

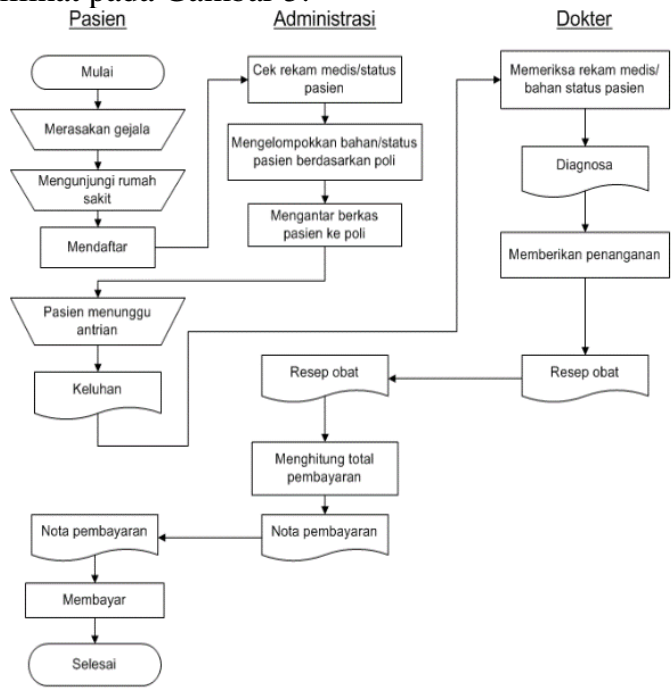

Gambar 5 Flowchart Sistem yang Sedang Berjalan

\section{D.2. Akuisisi dan Representasi Pengetahuan}

Berikut ini merupakan akuisisi dan representasi pengetahuan, dapat dilihat pada Tabel 2, Tabel 3, dan Tabel 4.

Tabel 2 Jenis Penyakit Menular Pada Anak Balita

\begin{tabular}{|c|l|}
\hline $\begin{array}{c}\text { Kode } \\
\text { Penyakit }\end{array}$ & \multicolumn{1}{|c|}{ Nama Penyakit Menular Pada Anak Balita } \\
\hline P01 & Campak / Morbili \\
\hline P02 & Rubella (Campak Jerman) \\
\hline P03 & Cacar Air / Varisela \\
\hline P04 & Sindrom Pipi Merah (Eritema infeksiosa) \\
\hline P05 & Roseola infantum \\
\hline
\end{tabular}

\begin{tabular}{|l|l|}
\hline P06 & Impetigo \\
\hline P07 & Demam Berdarah \\
\hline
\end{tabular}

Tabel 3 Gejala Penyakit Menular Pada Anak Balita

\begin{tabular}{|c|c|}
\hline $\begin{array}{l}\text { Kode } \\
\text { Gejala }\end{array}$ & $\begin{array}{c}\text { Nama Gejala Penyakit Menular Pada Anak } \\
\text { Balita }\end{array}$ \\
\hline G01 & Suhu badan di atas 38 derajat Celcius \\
\hline G02 & Mata berair dan merah pada bagian konjungtiva \\
\hline G03 & Batuk \\
\hline G04 & Pilek \\
\hline G05 & Bercak putih di dalam rongga mulut \\
\hline G06 & Muncul kelainan kemerahan pada kulit \\
\hline G07 & $\begin{array}{l}\text { Ruam biasanya berwarna coklat kemerahan } \\
\text { yang memenuhi seluruh tubuh dalam waktu } 3 \\
\text { hari }\end{array}$ \\
\hline G08 & Ruam akan memudar pada hari ke- 5 atau ke- 6 \\
\hline G09 & Suhu badan di bawah 38 derajat Celcius \\
\hline G10 & Sakit kepala \\
\hline G11 & $\begin{array}{l}\text { Pembesaran kelenjar getah bening di belakang } \\
\text { telinga pada leher }\end{array}$ \\
\hline G12 & $\begin{array}{l}\text { Ruam berwarna merah muda yang biasanya } \\
\text { muncul dalam waktu } 24-48 \text { jam sudah } \\
\text { menyeluruh }\end{array}$ \\
\hline G13 & Ruam berbentuk bintik-bintik merah kecil \\
\hline G14 & $\begin{array}{l}\text { Pada hari ke- } 3 \text { ruam di bagian tubuh mulai } \\
\text { memudar kemudian hilang }\end{array}$ \\
\hline G15 & Mengalami mual \\
\hline G16 & Timbulnya ruam pada kulit \\
\hline G17 & $\begin{array}{l}\text { Bekas cacar air akan membentuk cekungan } \\
\text { dangkal merah muda kemudian berangsur- } \\
\text { angsur menghilang }\end{array}$ \\
\hline G18 & Ruam terasa gatal \\
\hline G19 & Merasakan gangguan pernafasan \\
\hline G20 & Pipi anak berwarna merah \\
\hline G21 & Merasakan sakit kerongkongan \\
\hline G22 & $\begin{array}{l}\text { Ruam seperti tamparan, setelah lewat dari } 2-4 \\
\text { hari ruam menyebar ke tubuh, lengan, dan kaki }\end{array}$ \\
\hline G23 & $\begin{array}{l}\text { Terjadinya penurunan demam secara_rastic } \\
\text { menjadi normal }\end{array}$ \\
\hline G24 & Ruam berwarna merah tua \\
\hline G25 & Merasakan sakit/radang tenggorokan \\
\hline G26 & Tidak nafsu makan \\
\hline G27 & Mengalami diare ringan \\
\hline G28 & Mengalami kejang \\
\hline G29 & $\begin{array}{l}\text { Pada infeksi impetigo jaringan tempat terjadi } \\
\text { infeksi berada di sekitar lubang hidung dan } \\
\text { mulut }\end{array}$ \\
\hline G30 & $\begin{array}{l}\text { Biasanya pasien memiliki keluhan adanya } \\
\text { bintik-bintik yang berwarna kuning seperti } \\
\text { madu }\end{array}$ \\
\hline G31 & $\begin{array}{l}\text { Bintik-bintik tersebut seperti benjolan dan berisi } \\
\text { cairan yang dapat pecah sehingga menyebabkan } \\
\text { kemerahan }\end{array}$ \\
\hline G32 & $\begin{array}{l}\text { Bintik-bintik tersebut melepuh dan berisi nanah } \\
\text { dan berkopeng }\end{array}$ \\
\hline G33 & $\begin{array}{l}\text { Demam tinggi secara mendadak dan terus- } \\
\text { menerus selama 2-7 hari }\end{array}$ \\
\hline G34 & Terjadi pendarahan terutama pendarahan kulit \\
\hline G35 & Mengalami pendarahan gusi \\
\hline G36 & $\begin{array}{l}\text { Mengalami mimisan dan buang air besar } \\
\text { berdarah }\end{array}$ \\
\hline G37 & Merasakan nyeri perut \\
\hline G38 & $\begin{array}{l}\text { Ruam kemerahan muncul sekitar 2-5 hari } \\
\text { setelah demam }\end{array}$ \\
\hline G39 & Anak mengalami muntah \\
\hline G40 & Kesadaran anak menurun \\
\hline G41 & Mengalami fase syok, gelisah, dan lesu \\
\hline G42 & Demam tinggi \\
\hline G43 & Pendarahan konjungtivitis \\
\hline G44 & Demam ringan \\
\hline G45 & $\begin{array}{l}\text { Terdapat benjolan di belakang telinga pada } \\
\text { leher yang disebabkan oleh pembengkakan }\end{array}$ \\
\hline
\end{tabular}




\begin{tabular}{|c|c|}
\hline $\begin{array}{c}\text { Kode } \\
\text { Gejala }\end{array}$ & \multicolumn{1}{|c|}{ Nama Gejala Penyakit Menular Pada Anak } \\
\hline & Balita \\
\hline & kelenjar getah bening \\
\hline
\end{tabular}

Tabel 4Relasi antara Gejala dengan Penyakit

\begin{tabular}{|c|c|c|c|c|c|c|c|}
\hline Kode & \multicolumn{7}{|c|}{ Kode Penyakit } \\
\hline & P01 & P02 & P03 & P04 & P05 & P06 & P07 \\
\hline G01 & $*$ & & & & & & \\
\hline G02 & $*$ & $*$ & & & & & \\
\hline G03 & $*$ & $*$ & & $*$ & $*$ & & $*$ \\
\hline G04 & $*$ & & & $*$ & $*$ & & \\
\hline G05 & $*$ & & & & & & \\
\hline G06 & $*$ & $*$ & & & $*$ & & \\
\hline G07 & $*$ & & & & & & \\
\hline G08 & $*$ & & & & & & \\
\hline G9 & & $*$ & $*$ & $*$ & & & \\
\hline G10 & & $*$ & $*$ & & & & \\
\hline G11 & & $*$ & & & & & \\
\hline G12 & & $*$ & & & & & \\
\hline G13 & & $*$ & & & & & \\
\hline G14 & & $*$ & & & & & \\
\hline G15 & & & $*$ & & & & $*$ \\
\hline G16 & & & $*$ & & & & \\
\hline G17 & & & $*$ & & & & \\
\hline G18 & & & $*$ & & & & \\
\hline G19 & & & & $*$ & & & \\
\hline G20 & & & & $*$ & & & \\
\hline G21 & & & & $*$ & & & \\
\hline G22 & & & & $*$ & & & \\
\hline G23 & & & & & $*$ & & \\
\hline G24 & & & & & $*$ & & \\
\hline G25 & & & & & $*$ & & \\
\hline G26 & & & & & $*$ & & \\
\hline G27 & & & & & $*$ & & \\
\hline G28 & & & & & $*$ & & \\
\hline G29 & & & & & & $*$ & \\
\hline G30 & & & & & & $*$ & \\
\hline G31 & & & & & & $*$ & \\
\hline G32 & & & & & & $*$ & \\
\hline G33 & & & & & & & $*$ \\
\hline G34 & & & & & & & $*$ \\
\hline G35 & & & & & & & $*$ \\
\hline G36 & & & & & & & $*$ \\
\hline G37 & & & & & & & $*$ \\
\hline G38 & & & & & & & $*$ \\
\hline G39 & & & & & & & $*$ \\
\hline G40 & & & & & & & $*$ \\
\hline G41 & & & & & & & $*$ \\
\hline G42 & $*$ & & & & & & $*$ \\
\hline G43 & $*$ & $*$ & & & & & \\
\hline G44 & & $*$ & $*$ & $*$ & & & \\
\hline G45 & & $*$ & & & & & \\
\hline & & & & & & & \\
\hline
\end{tabular}

Tabel 5 Rules (Aturan)

\begin{tabular}{|c|c|l|l|l|}
\hline Kode & & \multicolumn{1}{|c|}{ Rule (Aturan) } & & Hipotesis \\
\hline R1 & IF & $\begin{array}{l}\text { Suhu badan di atas 38 } \\
\text { derajat Celcius = "Ya" } \\
\text { (G01) }\end{array}$ & THEN & $\begin{array}{l}\text { Demam } \\
\text { tinggi } \\
\text { (G42) }\end{array}$ \\
\hline R2 & IF & $\begin{array}{l}\text { Mata berair dan merah } \\
\text { pada bagian } \\
\text { konjungtiva = "Ya" } \\
\text { (G2) }\end{array}$ & THEN & $\begin{array}{l}\text { Pendarah } \\
\text { an } \\
\text { konjungti } \\
\text { vitis } \\
\text { (G43) }\end{array}$ \\
\hline R3 & IF & $\begin{array}{l}\text { Suhu badan di atas 38 } \\
\text { derajat Celcius = "Ya" } \\
\text { (G01) }\end{array}$ & THEN & $\begin{array}{l}\text { Demam } \\
\text { tinggi } \\
\text { (G44) }\end{array}$ \\
\hline R4 & IF & $\begin{array}{l}\text { Pembesaran kelenjar } \\
\text { getah bening di } \\
\text { belakang telinga pada } \\
\text { leher = "Ya" (G11) }\end{array}$ & THEN & $\begin{array}{l}\text { Terdapat } \\
\text { benjolan } \\
\text { di } \\
\text { belakang } \\
\text { telinga }\end{array}$ \\
& & \multicolumn{2}{|l}{} \\
\hline
\end{tabular}

\begin{tabular}{|c|c|c|c|c|}
\hline & & & & $\begin{array}{l}\text { pada } \\
\text { leher } \\
\text { yang } \\
\text { disebabk } \\
\text { an oleh } \\
\text { pembeng } \\
\text { kakan } \\
\text { kelenjar } \\
\text { getah } \\
\text { bening } \\
\text { (G45) }\end{array}$ \\
\hline R5 & $I F$ & $\begin{array}{l}\text { Suhu badan di atas } 38 \\
\text { derajat Celcius = "ya" } \\
\text { (G01) AND mata } \\
\text { berair dan merah pada } \\
\text { bagian konjungtiva }= \\
\text { "ya" (G02) AND } \\
\text { batuk = "ya" (G03) } \\
\text { AND pilek = "ya" } \\
\text { (G04) AND bercak } \\
\text { putih di dalam rongga } \\
\text { mulut = "ya" (G05) } \\
\text { AND muncul kelainan } \\
\text { kemerahan pada kulit } \\
=\text { "ya" (G06) AND } \\
\text { ruam berwarna coklat } \\
\text { kemerahan yan } \\
\text { memenuhi seluruh } \\
\text { tubuh dalam } 3 \text { hari }= \\
\text { "ya" (G07) AND ruam } \\
\text { akan memudar pada } \\
\text { hari ke 5/6 = "ya" } \\
\text { (G08) }\end{array}$ & THEN & $\begin{array}{l}\text { Campak / } \\
\text { Morbili } \\
\text { (P01) }\end{array}$ \\
\hline R6 & $I F$ & $\begin{array}{l}\text { Mata berair dan merah } \\
\text { pada } \\
\text { konjungtiva }=\text { bagian } \\
(\mathrm{G} 02) \text { AND batuk } \\
\text { "ya" (G03) AND } \\
\text { muncul kelainan } \\
\text { kemerahan pada kulit } \\
=\text { "ya" (G06) AND } \\
\text { suhu di bawah } 38 \\
\text { derajat Celcius = "ya" } \\
\text { (G09) AND sakit } \\
\text { kepala = "ya" (G10) } \\
\text { AND pembengkakang } \\
\text { kelenjar getah bening } \\
\text { di belakang telinga } \\
\text { pada leher = "ya" } \\
\text { (G11) AND ruam } \\
\text { berwarna merah muda } \\
\text { yang biasanya muncul } \\
\text { dalam waktu 24-48 } \\
\text { jam sudah menyeluruh } \\
=\text { "ya" (G12) AND } \\
\text { ruam berbentuk bintik- } \\
\text { bintik merah kecil = } \\
\text { "ya" (G13) } \boldsymbol{A N D} \text { pada } \\
\text { hari ke- 3 ruam di } \\
\text { bagian tubuh mulai } \\
\text { memudar kemudian } \\
\text { hilang= "ya" (G14) }\end{array}$ & THEN & $\begin{array}{c}\text { Campak } \\
\text { Jerman/ } \\
\text { Rubella } \\
\text { (P02) }\end{array}$ \\
\hline R7 & IF & $\begin{array}{l}\text { Demam ringan = "ya" } \\
\text { (G09) AND sakit } \\
\text { kepala = "ya" (G10) } \\
\text { AND mengalami mual } \\
=\text { "ya" (G15) AND } \\
\text { timbulnya ruam pada } \\
\text { kulit = "ya" (G16) } \\
\text { AND bekas cacar air } \\
\text { akan membentuk } \\
\text { cekungan dangkal } \\
\text { merah muda kemudian } \\
\text { berangsu-angsu } \\
\text { menghilang = "ya" }\end{array}$ & THEN & $\begin{array}{c}\text { Cacar } \\
\text { Air/ } \\
\text { Varisela } \\
\text { (P03) }\end{array}$ \\
\hline
\end{tabular}




\begin{tabular}{|c|c|c|c|c|}
\hline & & $\begin{array}{lcc}\text { G17) } & \text { AND } & \text { ruam } \\
\text { terasa } & \text { gatal }= & \text { "ya" } \\
(\text { G18) } & & \end{array}$ & & \\
\hline R8 & $I F$ & $\begin{array}{l}\text { Batuk = "ya" (G03) } \\
\text { AND pilek = "ya" } \\
\text { (G04) AND suhu di } \\
\text { bawah } 38 \text { derajat } \\
\text { Celcius = "ya" (G09) } \\
\text { AND merasakan } \\
\text { gangguan pernafasan } \\
=\text { "ya" (G19) AND } \\
\text { pipi anak berwarna } \\
\text { merah = "ya" (G20) } \\
\text { AND merasakan sakit } \\
\text { kerongkongan = "ya" } \\
\text { (G21) AND ruam } \\
\text { seperti tamparan } \\
\text { setelah lewat dari 2-4 } \\
\text { hari ruam menyebar ke } \\
\text { tubuh, lengan, dan } \\
\text { kaki= "ya" (G22) }\end{array}$ & THEN & $\begin{array}{l}\text { Sindrom } \\
\text { Pipi } \\
\text { Merah / } \\
\text { Eritema } \\
\text { infeksios } \\
a(\mathrm{P04})\end{array}$ \\
\hline R9 & $I F$ & 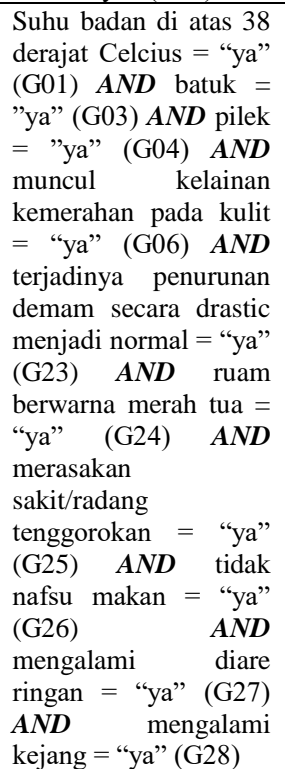 & THEN & $\begin{array}{l}\text { Roseola } \\
\text { infantum } \\
\text { (P05) }\end{array}$ \\
\hline R10 & IF & $\begin{array}{l}\text { Pada infeksi impetigo } \\
\text { jaringan tempat } \\
\text { terjadinya infeksi } \\
\text { berada di sekitar } \\
\text { lubang hidung dan } \\
\text { mulut = "ya" (G29) } \\
\text { AND biasanya pasien } \\
\text { memiliki keluhan } \\
\text { adanya bintik-bintik } \\
\text { berwarna kuning } \\
\text { seperti madu = "ya" } \\
\text { (G30) AND bintik- } \\
\text { bintik tersebut seperti } \\
\text { benjolan dan berisi } \\
\text { cairan yang dapat } \\
\text { pecah sang sangga } \\
\text { menyebabkan } \\
\text { kemerah = "ya" } \\
\text { (G31) AND bintik- } \\
\text { bintik tersebut } \\
\text { melepuh dan berisi } \\
\text { nanah dan berkopeng } \\
=\text { "ya" (G32) }\end{array}$ & THEN & $\begin{array}{c}\text { Impetigo } \\
\text { (P06) }\end{array}$ \\
\hline R11 & IF & $\begin{array}{l}\text { Suhu badan di atas } 38 \\
\text { derajat Celcius = "ya" } \\
\text { (G01) AND batuk = } \\
\text { "ya" (G03) } \boldsymbol{A N D} \\
\text { mengalami mual = } \\
\text { "ya" (G15) } \boldsymbol{A N D} \\
\text { demam tinggi secara }\end{array}$ & THEN & $\begin{array}{c}\text { Demam } \\
\text { Berdarah } \\
\text { (P07) }\end{array}$ \\
\hline
\end{tabular}

\begin{tabular}{|l|l|l|}
\hline & $\begin{array}{l}\text { mendadak dan terus- } \\
\text { menerus selama 2-7 } \\
\text { hari = "ya" (G33) } \\
\text { AND terjadinya } \\
\text { pendarahan terutama } \\
\text { pendarahan kulit = } \\
\text { "ya" (G34) AND } \\
\text { mengalami gusi = } \\
\text { pendarahan gusi } \\
\text { "ya" (G35) AND } \\
\text { mengalami mimisan } \\
\text { dan buang air besar } \\
\text { berdarah = "ya" (G36) } \\
\text { AND merasakan nyeri } \\
\text { perut = "ya" (G37) } \\
\text { AND ruam kemerahan } \\
\text { muncul sekitar 2-5 } \\
\text { hari setelah demam = } \\
\text { "ya" (G38) AND anak } \\
\text { mengalami muntah = } \\
\text { "ya" (G39) AND } \\
\text { kesadaran a anak } \\
\text { menurun= "ya" (G40) } \\
\text { AND mengalami fase } \\
\text { syok= "ya" (G41) }\end{array}$ & \\
\end{tabular}

\section{D.3. Perancangan Sistem Pakar}

Setelah melakukan analisa system, maka langkah selanjutnya adalah merancangan system. Rancangan aplikasi ada dalam bentuk flowchart, perancangan struktur menu, dan rancangan interface aplikasi.

a. Use Case Diagram

Berikut ini merupakan use case diagram sistem pakar yang dapat dilihat pada Gambar 4.2.

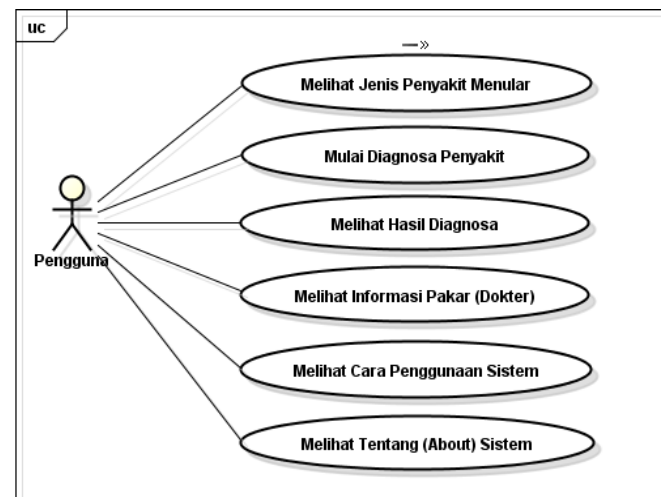

Gambar 4.2 Use Case Diagram

b. Struktur Menu

Berikut ini merupakan rancangan struktur menu sistem pakar yang dapat dilihat pada Gambar 6. 


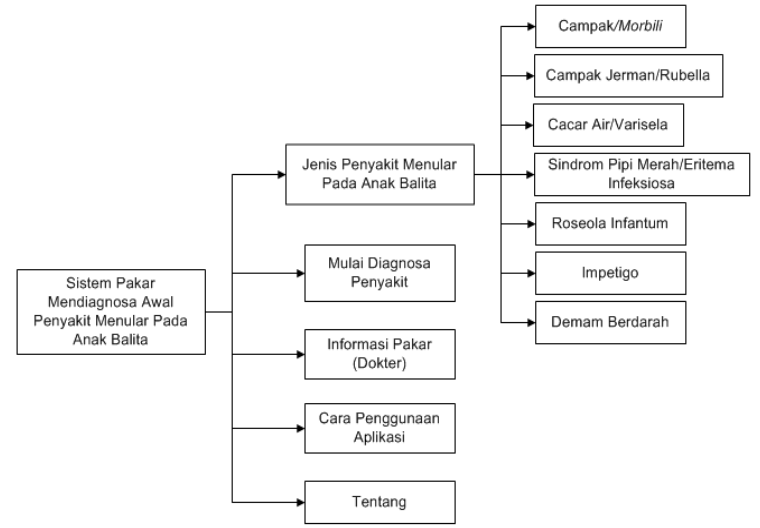

Gambar 6 Struktur Menu Sistem Pakar

c. Interface Sistem Pakar

Berikut ini merupakan rancangan struktur menu sistem pakar yang dapat dilihat pada Gambar 7 dan Gambar 8.
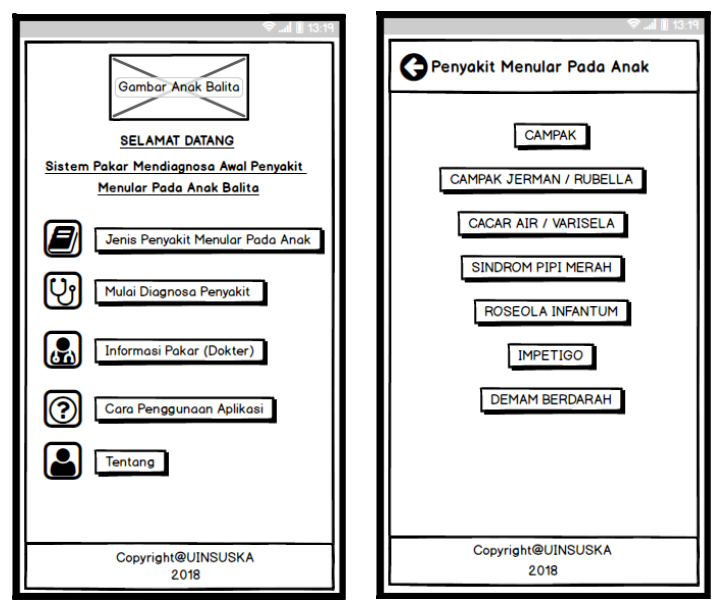

Gambar 7 Halaman Utama Aplikasi Sistem Pakar dan Halaman Jenis Penyakit Menular

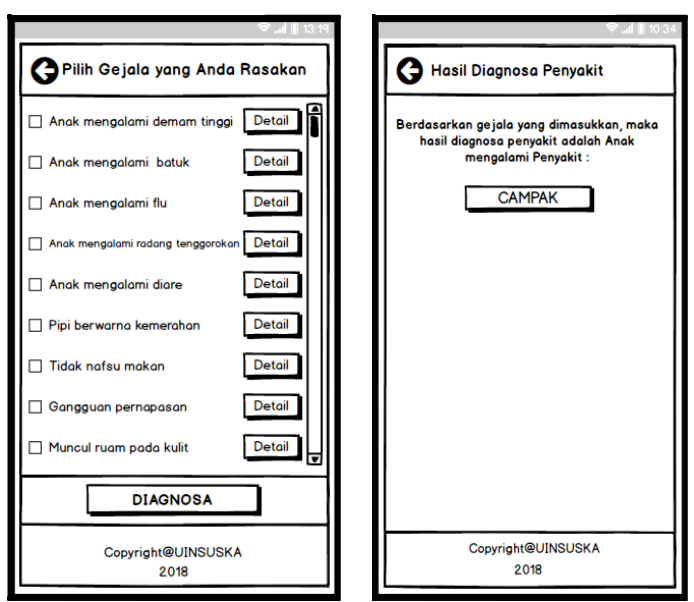

Gambar 8 Halaman Mulai Diagnosa Penyakit dan Halaman Hasil Diagnosa

\section{E. IMPLEMENTASI}

E.1. Implementasi Sistem

a. Batasan Implementasi

Batasan implementasi dari sistem pakar diagnosa awal penyakit menular pada anak balita dengan mengggunakan metode forward chaining adalah:

1) Sistem pakar dibangun menggunakan android studio.

2) Sistem pakar dibangun menggunakan bahasa pemograman java.

3) Pada aplikasi pengguna dapat mengetahui informasi mengenai jenis penyakit menular pada anak balita, penyebab dan penanganan awal penyakit menular, serta informasi dokter spesialis anak yang terlibat dalam pembuatan aplikasi sistem pakar ini.

4) Pengguna sistem pakar adalah pengunjung aplikasi, pengguna yang menginstalasi aplikasi ke android mereka.

b. Hasil Implementasi

Berikut ini merupakan rancangan struktur menu sistem pakar yang dapat dilihat pada Gambar 9, Gambar 10, Gambar 11, dan Gambar 12.
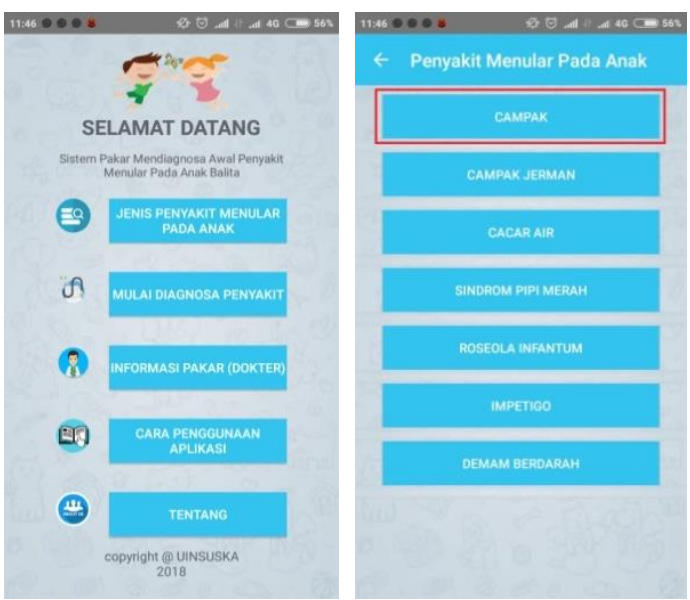

Gambar 9 Halaman Utama dan Halaman Menu Jenis Penyakit Menular Pada Anak Balita

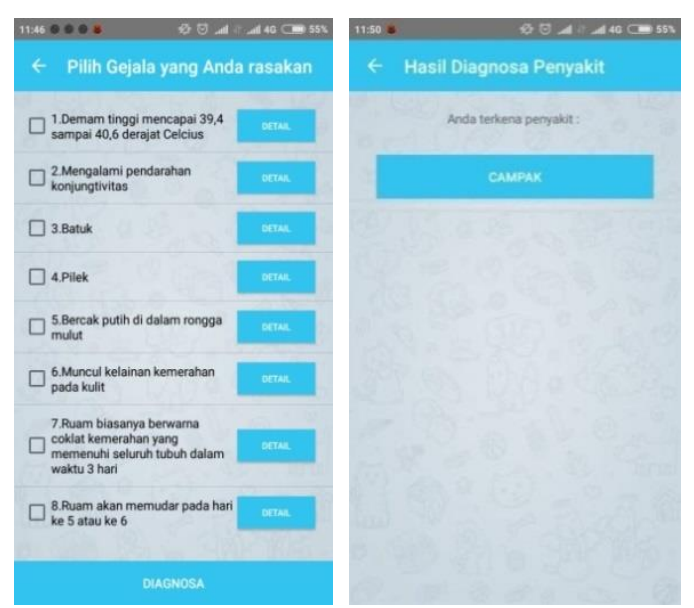

Gambar 10 Menu Diagnosa Penyakit dan Halaman Hasil Diagnosa Penyakit 

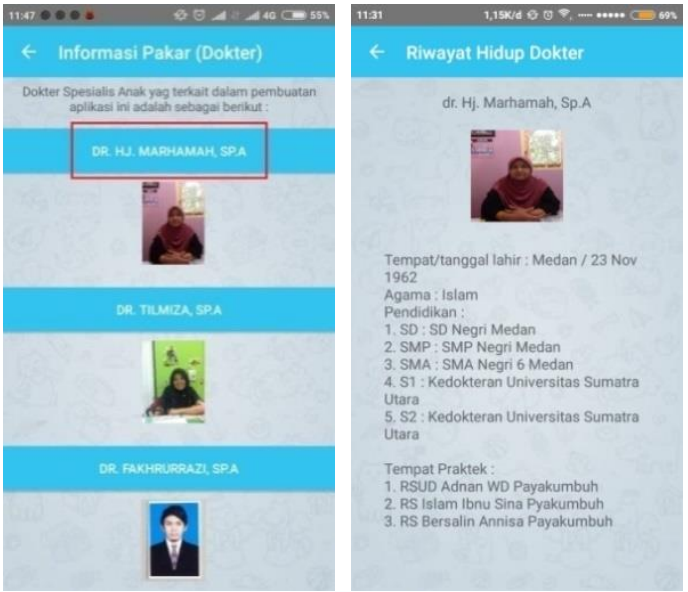

Gambar 11 Menu Informasi Pakar (Dokter)
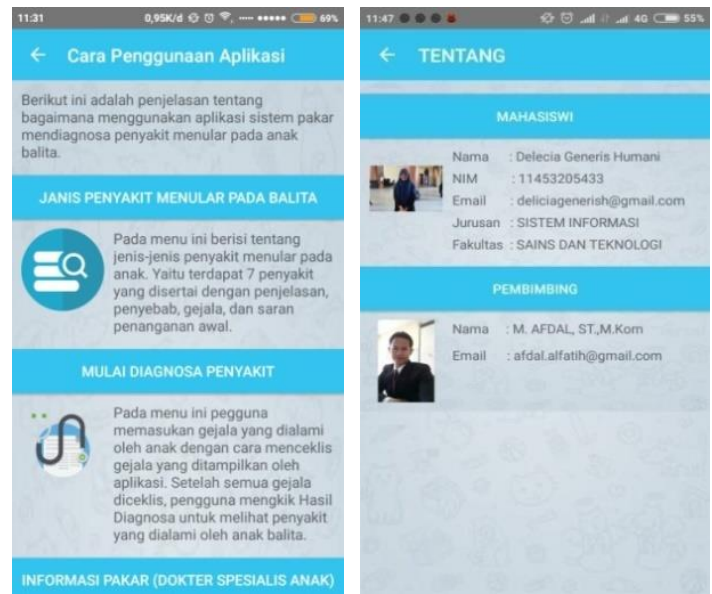

Gambar 12 Menu Cara Penggunaan dan Menu Tentang

\section{E.2. Pengujian}

Pengujian sistem dilakukan dengan tujuan untuk menjamin sistem yang dibangun sesuai dengan hasil analisa dan perancangan sehingga dapat dibuat suatu kesimpulan akhir.

a. Unit Testing

Pengujian UT dilakukan untuk menguji coba program terhadap rule-rule (aturan) yang telah dibuat sebelumnya, apakah inferensi yang dilakukan sesuai dengan yang diharapkan. Hasil pengujian UT (unit testing) dapat dilihat pada tabel 6.

Tabel 6 Hasil Pengujian UT

\begin{tabular}{|c|c|c|c|c|}
\hline No & \multicolumn{1}{|c|}{ Test case } & $\begin{array}{c}\text { Output } \\
\text { yang } \\
\text { diharap } \\
\text { kan }\end{array}$ & Benar & Salah \\
\hline 1. & $\begin{array}{l}\text { Suhu badan di } \\
\text { atas 38 derajat } \\
\begin{array}{l}\text { Celcius = "Ya" } \\
\text { G01) }\end{array}\end{array}$ G42 & $\sqrt{ }$ & - \\
\hline 2. & $\begin{array}{l}\text { Mata berair dan } \\
\text { merah pada } \\
\text { bagian } \\
\text { konjungtiva } \\
\text { "Ya" (G2) }\end{array}$ & G43 & $\sqrt{ }$ & - \\
\hline
\end{tabular}

b. Blackbox Testing
Pengujian sistem menggunakan metode blackbox dari dilakukan pada 10 smartphone dengan spesifikasi yang berbeda. Persentasi keberhasilan pengujian aplikasi sistem pakar diagnosa penyakit menular pada anak balita menggunakan metode blackbox adalah 100\%. Hasil pengujian blackbox testing dapat dilihat pada Tabel 7.

Tabel 7 Hasil Pengujian Blackbox

\begin{tabular}{|c|c|c|c|c|}
\hline \multirow{2}{*}{ Nama } & \multicolumn{2}{|c|}{ Hasil Pengujian } & \multirow{2}{*}{\multicolumn{2}{|c|}{$\begin{array}{c}\text { Persentasi } \\
\text { Keberhasilan }\end{array}$}} \\
\hline & Berhasil & Gagal & & \\
\hline Device 1 & 11 & 0 & $\begin{array}{c}\frac{11 x}{100 \%} \\
17\end{array}$ & $=100 \%$ \\
\hline Device 2 & 11 & 0 & $\begin{array}{r}11 \mathrm{x} \\
100 \% \\
17 \\
\end{array}$ & $=100 \%$ \\
\hline Device 3 & 11 & 0 & $\begin{array}{c}\frac{11 x}{100 \%} \\
17\end{array}$ & $=100 \%$ \\
\hline Device 4 & 11 & 0 & $\begin{array}{r}11 \mathrm{x} \\
100 \% \\
17\end{array}$ & $=100 \%$ \\
\hline Device 5 & 11 & 0 & $\begin{array}{c}11 x \\
100 \% \\
17\end{array}$ & $=100 \%$ \\
\hline Device 6 & 11 & 0 & $\begin{array}{c}11 x \\
100 \% \\
17\end{array}$ & $=100 \%$ \\
\hline Device 7 & 11 & 0 & $\begin{array}{c}\frac{11 x}{100 \%} \\
17\end{array}$ & $=100 \%$ \\
\hline Device 8 & 11 & 0 & $\begin{array}{c}\frac{11 x}{100 \%} \\
17\end{array}$ & $=100 \%$ \\
\hline Device 9 & 11 & 0 & $\begin{array}{c}\frac{11 x}{100 \%} \\
17\end{array}$ & $=100 \%$ \\
\hline Device 10 & 11 & 0 & $\begin{array}{c}\frac{11 x}{100 \%} \\
17\end{array}$ & $=100 \%$ \\
\hline & a-rata & & 100 & \\
\hline
\end{tabular}

c. User Acceptance Test

Pengujian user acceptance test merupakan pengujian yang dilakukan berdasarkan hasil kuisioner yang sebelumnya telah dibagikan kepada user. Hasil pengujian aplikasi menggunakan UAT dapat dilihat pada Tabel 8.

Tabel 8 Hasil Pengujian UAT

\begin{tabular}{|c|c|}
\hline Pertanyaan & Tingkat Penerimaan \\
\hline Pertanyaan 1 & $95 \%$ \\
\hline Pertanyaan 2 & $92,5 \%$ \\
\hline Pertanyaan 3 & $92,5 \%$ \\
\hline Pertanyaan 4 & $85 \%$ \\
\hline Pertanyaan 5 & $90 \%$ \\
\hline Rata-rata & $91 \%$ \\
\hline
\end{tabular}

\section{F. Penutup}

\section{F.1 Kesimpulan}

Berdasarkan hasil penelitian yang dilakukan, maka kesimpulan yaitu:

1. Aplikasi sistem pakar untuk mendiagnosa awal penyakit menular pada anak balita menerapkan metode forward chaining dalam menghasilkan kesimpulan. 
2. Aplikasi sistem pakar untuk mendiagnosa awal penyakit menular pada anak balita memiliki 5 menu utama yang dapat diakses, yaitu Menu Jenis Penyakit Menular Pada Anak, Menu Diagnosa Penyakit, Menu Informasi Pakar (Dokter), Menu Cara Penggunaan, dan Menu Tentang.

3. Hasil pengujian fungsional aplikasi sistem pakar untuk mendiagnosa awal penyakit menular pada anak balita dengan pengujian UT (unit testing) memiliki persentasi keberhasilan sebesar 100\%. Pengujian UT dilakukan terhadap 7 rule (aturan).

4. Hasil pengujian fungsional aplikasi sistem pakar untuk mendiagnosa penyakit menular pada anak balita dengan pengujian blackbox memiliki persentasi keberhasilan sebesar $100 \%$. Pengujian blackbox dilakukan terhadap 11 buti uji dan pada 10 device (smartphone) yang berbeda spesifikasi.

5. Hasil pengujian UAT (user acceptance test) aplikasi sistem pakar untuk mendiagnosa awal penyakit menular pada anak balita memiliki persentasi sebesar $91 \%$ penerimaan.

\section{F.2. Saran}

Berikut ini saran yang diajukan berdasarkan kesimpulan di atas, yaitu:

1. Aplikasi dapat dikembangkan dengan menggunakan metode yang berbeda, sehingga didapatkan perbandingan antara sistem yang dibangun dengan metode yang digunakan.

2. Untuk penelatian selanjutnya, diharapkan dapat memperbaharui tampilannya sehingga terlihat lebih menarik.

3. Diharapkan dapat memperbaharui gejala penyakit menular pada anak balita serta penyempurnaan mengenai informasi seputar penyakit menular pada anak balita yang tidak hanya terbatas pada penyakit menuxlar pada anak balita yang dapat didiagnosa awal saja.

\section{REFERENSI}

[1] Achmadi, U. F. "Dasar-Dasar Penyakit Berbasis Lingkungan," Jakarta: PT. Rajagrafindo, 2011.

[2]Sekretariat Jenderal Kementerian Kesehatan Indonesia. "Profil Kesehatan Indonesia Tahun 2015," Jakarta: 2015.

[3]Widoyono.2008. "Penyakit Tropis: Epidemiologi, Penularan, Pencegahan, dan Pemberantasannya," Jakarta:Erlangga.

[4]Kementerian Kesehatan Republik Indonesi Tahun 2018., [Online] Available http://www.depkes.go.id/article/view/18082400002/fa twa-mui-bolehkan-imunisasi-campak-dan-rubellakemenkes-fokus-turunkan-beban-dan-dampakpenyakit-te.html

[5]Latamukalita, Luther A. "Sistem Pakar Pendiagnosa Penyakit Anak Menggunakan Certainty Factor (CF)," Jurnal Ilmiah Sains. Vol. 12 No. 2 Oktober 2012.

[6]www.republika.co.id [Online] Available https://www.republika.co.id/ berita/nasional/jabodetabeknasional/14/10/01/ncr7ix-idi-sebut-ju\%20lah-dokterspesialis-masih-minim.

[7]Turban E. Decision Support System an Intelligent Systems Edisi Bahasa Indonesia Jilid 1. Yogyakarta. Andi, Yogyakarta. 2005.

[8]Sutojo, T.; Mulyanto, Edy; Suhartono, Vincent.Kecerdasan Buatan. Yogyakarta: ANDI. 2011.

[9]Listiyono, Hersatoto. "Merancang dan Membuat Sistem Pakar," Jurnal Teknologi Informasi DINAMIK. Volume XIII, No.2, Juli 2008, hal. 115124. ISSN : 0854-9524. 